\title{
APLIKASI EKSTRAK BAWANG MERAH TERHADAP PERTUMBUHAN OKULASI TANAMAN JERUK MANIS (Citrus Sp.)
}

\author{
Yondi Yanengga, Sumiyati Tuhuteru* \\ Program Studi Agroteknologi, Sekolah Tinggi Ilmu Pertanian Petra Baliem Wamena, Papua, 99511 \\ *Email: sumiyati.tuhuteru@yahoo.com
}

Diserahkan: 15 Februari 2020

Diterima: 7 Desember 2020

\begin{abstract}
ABSTRAK.
Kebutuhan akan buah jeruk dari tahun ke tahun terus meningkat. Berbagai upaya terus dilakukan untuk meningkatkan produktivitas tanaman jeruk. Salah satunya adalah melalui perbanyakan vegetatif seperti okulasi dengan bantuan ZPT ekstrak bawang merah. Pelaksanaan penelitian dilakukan selama 2 (dua) bulan yaitu mulai bulan September - Oktober 2018. Alasan penelitian ini dilaksanakan adalah karena sejauh ini penggunaan ekstrak bawang merah dalam okulasi jeruk belum banyak dilakukan di dataran Wamena. Tujuan penelitian ini adalah mengetahui pengaruh ekstrak bawang merah terhadap okulasi tanaman jeruk (Citrus sp.) dan konsentrasi ekstrak bawang merah berapaka yang terbaik bagi keberhasilan okulasi, dengan rancangan penelitian yang digunakan adalah Rancangan Acak Kelompok yang terdiri dari 4 aras konsentrasi ekstrak bawang merah dan apabila menunjukkan pengaruh nyata maka akan dianalisis lanjut dengan uji BNT (Tukey) taraf $5 \%$. Masing-masing perlakuan diulang sebanyak 3 kali, macam perlakuannya adalah: MO (Konsentrasi 0\% (300 ml air tanpa ekstrak bawang merah); M1 (Konsentrasi 25\%); M2 (Konsentrasi 50\%); M3 (Konsentrasi 75\%). Hasil penelitian menunjukkan bahwa ekstrak bawang merah berpengaruh nyata terhadap saat munculnya tunas (HSO), jumlah daun (helai), tinggi tunas (cm), persentase keberhasilan okulasi hidup (\%) yang ditunjukkan oleh konsentrasi ekstrak bawang merah 50\% (perlakuan M2).
\end{abstract}

Kata kunci: Citrus; Ekstrak Bawang Merah; Jeruk Manis; Okulasi.

\section{PENDAHULUAN}

Jeruk (Citrus $S p$ ) adalah salah satu buah lokal yang berasal dari Indonesia. Tanaman ini banyak dijumpai di wilayah Negara kita Indonesia. Ada berbagai macam atau jenis yang terdapat di Indonesia seperti jeruk manis, jeruk sambal, jeruk nipis, jeruk bali, dan lain-lain. Buah ini dapat tumbuh di dataran rendah bahkan dataran tinggi.

Kebutuhan akan buah jeruk dari tahun ke tahun meningkat. Hal ini disebabkan karena masyarakat menyukai buah ini dimana buah ini merupakan buah yang kaya akan vitamin $\mathrm{C}$ dan perilaku masyarakat yang suka akan buah segar. Meningkatnya kebutuhan akan buah jeruk, sampai-sampai pemerintah mendatangkan buah jeruk dari luar negeri atau mengekspor buah jeruk.

Kabupaten Jayawijaya merupakan salah satu kabupaten di Pegunungan Tengah yang juga memiliki produk andalan di bidang pertanian salah satunya yaitu buah jeruk. Buah jeruk di kabupaten ini terkenal beda apabila dibandingkan dengan jeruk dari daerah lain. Jeruk dari pegunungan tengah terkenal berasal dari daerah Kimbim (BPS, 2017). Selain itu jeruk dengan rasa manis ini sangat disukai oleh masyarakat karena rasa manisnya berbeda sekali. Hal ini karena dalam budidaya jeruk di daerah pegunungan tengah pada umumnya tidak memakai bahan kimia. Selain itu, disebabkan karena adanya peraturan daerah yang melarang penggunaan 
bahan kimia di daerah Pegunungan Tengah pada umumnya dan Kabupaten Jayawijaya pada khususnya.

Budidaya tanaman jeruk pada umumnya memerlukan waktu yang tidak sedikit bahkan bisa memakan waktu bertahun-tahun untuk sampai panennya. Oleh karena itu ada berbagai cara untuk mempercepat perkembangbiakannya yaitu dengan perkembangbiakan secara vegetatif atau perkembangan secara tidak kawin. Salah satu cara perkembangbiakan vegetatif tersebut adalah dengan okulasi.

Okulasi merupakan proses pertautan antara batang atas/mata tempel varietas tertentu dengan batang bawah terpilih, proses menggabungkan dua sifat yang berbeda antara batang atas dan batang bawah (Hardiyanto et al. 2010). Salah satu keberhasilan okulasi juga ditentukan oleh adanya tambahan Zat Pengatur Tumbuh (ZPT), seperti ekstrak bawang merah yang diketahui mengandung salah satu hormon tumbuh seperti Auksin (IAA).

Zat pengatur tumbuh adalah suatu bahan yang dibuat untuk memacu pertumbuhan tanaman guna pembentukan fitohormon (hormon tumbuhan) yang sudah ada di dalam tanaman atau menggantikan fungsi dan peran hormon. Zat pengatur tumbuh (ZPT) adalah senyawa alami maupun sintetik yang dalam konsentrasi rendah dapat mengatur, merangsang atau menghambat pertumbuhan dan perkembangan sel tanaman. Zat pengatur tumbuh yang dihasilkan oleh tanaman disebut fitohormon, sedangkan yang berasal dari luar tanaman secara buatan disebut ZPT sintetik (Wattimena, 1988).

Pemanfaatan ZPT untuk pematahan dormansi mata tempel okulasi tanaman jeruk merupakan salah satu teknik yang dapat dipilih untuk diterapkan. Ekstrak bawang merah memiliki kandungan zat pengatur tumbuh (ZPT) yang merangsang mata tunas dan proses perakaran, ekstrak bawang merah memiliki kandungan yang merangsang tumbuhan adalah sebagai berikut: Umbi bawang merah mengandung vitamin B1 (Thiamin) untuk pertumbuhan tunas, riboflavin untuk pertumbuhan, asam nikotinat sebagai koenzim, serta mengandung zpt auksin dan rhizokalin yang dapat merangsang pertumbuhan akar (Rahayu dan Berlian, 1999).

Saat ini di Kabupaten Jayawijaya sendiri masih melakukan sistem pertanian tradisional dan belum mengenal okulasi. Meski diketahui bahwa, sistem pertanian yang diterapkan adalah sistem pertanian organik. Untuk itu, penelitian ini dilakukan untuk mengetahui pengaruh ekstrak bawang merah terhadap okulasi tanaman jeruk manis di Distrik Kurulu, Kabupaten Jayawijaya dan konsentrasi berapakah okulasi tersebut tumbuh dan berkembang dengan baik, dengan hipotesis diduga konsentrasi ekstrak bawang merah $75 \%$ memberikan pengaruh yang terbaik bagi pertumbuhan secara okulasi pada tanaman jeruk. 


\section{METODOLOGI PENELITIAN}

\section{Waktu Dan Tempat Penelitian}

Penelitian ini dilaksanakan pada pertanaman jeruk manis di Distrik Kurulu, Kabupaten Jayawijaya Provinsi Papua. Pelaksanaan penelitian dilakukan selama 2 (dua) bulan yang berlangsung bulan September - Oktober 2018. Bahan yang di gunakan dalam penelitian ini adalah tanaman jeruk, bawang merah, tali rafia dan aqua. Sedangkan, alat yang di gunakan pisau cutter, plastik pembungkus, blender, penggaris dan alat tulis.

\section{Pembuatan Ekstrak Bawang Merah}

Bawang merah yang diperoleh dikupas kemudian diiris dan dihaluskan dengan menggunakan blender kemudian diambil ekstraknya dengan cara diperas. Pengenceran dilakukan dengan menambahkan air bersih sesuai dengan konsentrasi yang telah ditetapkan:

M0 : Konsentrasi 0\% (300 ml air tanpa ekstrak bawang merah)

M1 : Konsentrasi 25\% (75 ml air ekstrak bawang merah $+225 \mathrm{ml}$ air)

M2 : Konsentrasi 50\% (150 ml ekstrak bawang merah $+150 \mathrm{ml}$ air)

M3 : Konsentrasi 75\% (225 ml ekstrak bawang merah $+75 \mathrm{ml}$ air)

\section{Penyiapan Bahan Tanam}

Bahan tanam yang digunakan berupa stek batang yang diambil dari cabang tanaman jeruk yang memiliki kualitas dan pertumbuhan baik serta bebas penyakit. Kemudian, batang tanaman dipotong sepanjang $25 \mathrm{~cm}$, batang dipilih pada bagian yang lebih dekat dengan pangkal batang, dan diupayakan untuk tidak menggunakan batang tanaman yang umurnya terlalu muda karena akan memperbesar resiko kematian stek. Setelah pemotongan, bagian pangkal stek dicelupkan pada air bersih. Stek batang yang telah disiapkan kemudian direndam dalam ekstrak bawang merah dengan masing-masing konsentrasi yang telah ditentukan selama 30 menit sebelum proses okulasi.

\section{Pembuatan Okulasi}

a. Potong percabangan tanaman induk yang akan diambil mata tunasnya, yang dilakukan pada sore hari.

b. Buang daun-daun yang ada di percabangan, kemudian sayat mata tunas dengan menggunakan pisau cutter yang tekah dibilas bersih secara hatihati dari bawah ke atas.

c. Sayatan mata tunas kemudian direndam dengan konsentrasi ekstrak bawang merah sesuai dengan perlakuan selama 30 menit.

d. Sayat kulit percabangan primer secara hati-hati dengan ukuran $\pm 2 \mathrm{~cm}$ dan disesuaikan dengan panjang mata tunas yang disayat.

e. Kemudian dipotong setengah bagian sayatan kulit percabangan primer tersebut.

f. Tempelkan mata tunas dikambium percabangan primer tersebut.

g. Kemudian, tutup dengan setengah bagian kulit percabangan primer yang 
tidak dipotong dan jangan sampai mengenai mata tunas.

h. Bungkus mata tunas yang sudah menempel dengan plastik khusus okulasi yang sudah dipersiapkan sebelumnya. Pembukusan dilakukan dari arah bawah ke atas. Tujuannya agar mata tunas tertutup rapat atau kedap udara dan air siraman tidak bisa merembes masuk ke mata tunas. Untuk menghindari terjadinya pembusukkan mata tunas.

\section{Parameter Pengamatan}

Saat Muncul Tunas (HSO): Waktu Awal Muncul Tunas diamati setiap minggu setelah di okulasi pada setiap perlakuan.

Tinggi Tunas $(\mathrm{cm})$ : Tinggi tunas dihitung sebanyak 2 (dua) kali yaitu pada 30 HSO (Hari Setelah Okulasi) dan 60 HSO, dengan mengukur tinggi tunas dari pangkal tunas sampai pucuk tertinggi menggunakan penggaris.

Jumlah Daun (helai): Jumlah daun dihitung sebanyak 2 (dua) kali yaitu pada saat 30 HSO (Hari Setelah Okulasi) dan 60 HSO, dengan menghitung jumlah daun yang telah terbuka sempurna.

\section{Persentase Keberhasilan Okulasi Hidup} (\%): Keberhasilan Okulasi Hidup dihitung pada akhir pengamatan (pada 60 HSO) dengan menghitung jumlah okulasi yang hidup dibagi jumlah okulasi dikalikan 100\%. Adapun rumus yang digunakan dalam perhitungan ini adalah:

$$
\frac{\text { Jumlah Okulasi Hidup }}{\text { Jumlah Okulasi Keseluruhan }} \times 100 \%
$$

\section{Analisis data}

Data hasil pengamatan dianalisis dengan analisis sidik ragam ANOVA, apabila berbeda nyata maka dilanjutkan dengan Uji Beda Nyata terkecil (BNT) pada taraf 5\%.

\section{HASIL DAN PEMBAHASAN}

Hasil penelitian pemanfaatan ekstrak bawang merah pada okulasi tanaman Jeruk Manis di Distrik Kurulu, Kabupaten Jayawijaya menunjukkan pengaruh nyata. Hal ini ditunjukkan pada masing-masing parameter pengamatan. Tabel 1 menunjukkan hasil pengamatan terhadap parameter saat munculnya tunas setelah okulasi (HSO), yang terlihat bervariasi. Perlakuan M0 (kontrol/tanpa perlakuan) menunjukkan respon terlama saat munculnya tunas atau pada hari ke-33 setelah okulasi. Sedangkan perlakuan tercepat saat munculnya tunas adalah perlakuan M2 (konsentrasi 50\%), yakni pada hari k 3-5 okulasi tunas telah muncul.

\begin{tabular}{cc} 
Tabel 1. Waktu Munculnya Tunas \\
\hline Perlakuan & Waktu (HSO) \\
\hline M0 & 33 \\
M1 & 24 \\
M2 & 5 \\
M3 & 10 \\
\hline
\end{tabular}

Pertumbuhan tunas-tunas pada tanaman jeruk yang diokulasi tersebut diduga disebabkan karena hormon yang terkandung pada ekstrak bawang merah berpengaruh terhadap diferensiasi atau pembelahan sel. Dengan pembelahan sel yang bagus, maka secara otomatis akan banyak tumbuh tunas dan 
keberhasilan hidupnya juga akan menjadi besar. Hormon yang terkandung dalam ekstrak bawang merah adalah auksin endogen. Menurut Raven et. al. (1986), auksin dapat meningkatkan plastisitas dinding sel. Pada saat dinding sel mengendur, sel mengalami pengembangan karena terjadi kenaikan tekanan osmotik sel, sehingga mengakibatkan tekanan turgor sel menjadi rendah. Rendahnya turgor memacu absorbsi air ke dalam sel yang mengakibatkan sel terus mengalami pemanjangan serta pengembangan. Sebagaimana dikemukakan oleh Moore (1989), bahwa auksin mendorong pemanjangan sel dengan cara mempengaruhi metabolisme dinding sel. Pemanjangan dan pengembangan dinding sel diakibatkan oleh kemampuan selulosa mikrofibril penyusun dinding sel yang dapat memanjang ataupun mengendur, yang selanjutnya berpengaruh pada saat munculnya tunas.

Pengamatan waktu awal muncul tunas merupakan pengamatan dimana tunas itu muncul pertama kali. Pada tabel 1 dapat dilihat bahwa pada konsentrasi 50\% (M2) tunas muncul pada 5 HSO diikuti dengan kosentrasi $75 \%$ (M3) pada 10 HSO, konsentrasi $25 \%$ (M1) pada 24 HSO dan yang paling lama tunas muncul yaitu pada konsentrasi 0\% (M0) yaitu pada 33 HSO. Dari hasil penelitian tersebut dapat dikatakan bahwa pada konsentrasi $0 \%$ (M0) merupakan konsentrasi yang paling lama dalam memunculkan tunas. Keterlambatan munculnya tunas tersebut diduga disebabkan karena tidak ada pemberian ekstrak bawang merah.

Ekstrak bawang merah memiliki kandungan zat pengatur tumbuh (ZPT) yang merangsang mata tunas dan proses perakaran, ekstrak bawang merah memiliki kandungan yang merangsang tumbuhan adalah sebagai berikut: Umbi bawang merah mengandung vitamin B1 (Thiamin) untuk pertumbuhan tunas, riboflavin untuk pertumbuhan, asam nikotinat sebagai koenzim, serta mengandung zpt auksin dan rhizokalin yang dapat merangsang pertumbuhan akar (Rahayu dan Berlian, 1999). Dalam penelitian Widiyastuti (1999) pemberian ekstrak bawang merah 50\% menghasilkan jumlah daun terbanyak dengan rerata 10,46 helai daun. Ekstrak bawang merah yang mengandung auksin dan vitamin B1 (thiamin) dapat memacu pembelahan sel pada stek batang jarak pagar (Halim, 2003).

Auksin dan vitamin B1 (thiamin) yang terdapat dalam ekstrak bawang merah mampu untuk merangsang pertumbuhan akar dan tunas (Iskandar, 1992). Thiamin dengan Allicin akan membentuk ikatan allithiamin yang mudah diserap oleh sel tumbuhan membentuk efek fisiologis dalam pertumbuhan tunas dan daun (Sudirja, 2010). Sebagaimana ditampilkan pada tabel 2 .

Hasil penelitian pemberian ekstrak bawang merah pada parameter jumlah daun pengamatan 30 dan $60 \mathrm{HSO}$ pengaruh nyata oleh perlakuan M2 (konsentrasi $50 \%$ ) dengan rerata sebesar 3,86 helai pada pengamatan 30 $\mathrm{HSO}$, yang berbeda nyata dengan perlakuan 
Kontrol (M0) dengan rerata sebesar 1,00 helai (Tabel 2). Hal yang sama juga ditunjukkan pada pengamatan $60 \mathrm{HST}$, dimana perlakuan M2 (Konsentrasi 50\%) berpengaruh nyata (6,40 helai), dan berpengaruh nyata terhadap perlakuan kontrol (2,86 helai).

Perkembangan tunas pada akhirnya berpengaruh kepada pembentukan daun tanaman, dimana jumlah daun terbanyak ditunjukkan oleh perlakuan M2 (konsentrasi $50 \%$ ). Hal ini menunjukkan bahwa larutan ekstrak bawang merah dapat meningkatkan jumlah daun. Penyerapan air dan unsur hara dalam tanah yang baik dan kandungan hormon auksin yang sesuai akan membantu meningkatkan perkembangan jaringan xylem sehingga akan memperlancar proses pengiriman unsur hara dari bawah ke atas. Apabila pengiriman unsure hara dari akar ke bagian atas tanaman lancar, maka secara tidak langsung akan terjadi peningkatan jumlah daun.

Tabel 2. Rerata Jumlah Daun

\begin{tabular}{ccc}
\hline \multirow{2}{*}{ Perlakuan } & \multicolumn{2}{c}{ Waktu Pengamatan } \\
\cline { 2 - 3 } & $30 \mathrm{HSO}$ & $60 \mathrm{HSO}$ \\
\hline M0 & $1,00 \mathrm{~d}$ & $2,86 \mathrm{~b}$ \\
M1 & $1,73 \mathrm{c}$ & $5,06 \mathrm{a}$ \\
M2 & $3,86 \mathrm{a}$ & $6,40 \mathrm{a}$ \\
M3 & $2,93 \mathrm{~b}$ & $5,86 \mathrm{a}$ \\
\hline BNT & 0,49 & 1,35 \\
\hline
\end{tabular}

Keterangan: nilai sekolom yang diikuti dengan huruf yang sama menunjukkan tidak berbeda nyata uji BNT $5 \%$

Hal ini sesuai dengan penelitian Widyastuti (2002) yang mengatakan bahwa ekstrak bawang merah dapat meningkatkan jumlah daun pada tanaman nanas.

Penggunaan bawang merah sebagai salah satu zat pengatur tumbuh telah dilakukan pada beberapa jenis tanaman. Penelitian Siskawati (2013) membuktikan bahwa, pemberian ekstrak bawang merah dengan konsentrasi $100 \%$ menghasilkan bobot basah dan kering tajuk tertinggi pada stek batang tanaman jarak pagar apabila dibandingkan dengan perlakuan pemberian ekstrak bawang merah dengan konsentrasi 0\%, 40\%, 60\%, dan 80\%. Selain itu, menurut Muswita (2011), auksin bertindak sebagai pendorong awal proses terbentuknya akar pada stek. Pendapat lain dikemukakan oleh Mangoendidjojo (2003) bahwa penambahan auksin eksogen akan meningkatkan kandungan auksin endogen dalam jaringan stek tersebut sehingga mampu menginisiasi sel untuk tumbuh dan berkembang yang selanjutnya akan berdiferensiasi membentuk organ seperti akar. Hal ini pada akhirnya berpengaruh pada proses pemanjangan dan pembesaran sel sehingga terbentuklah organ tanaman. Selain itu, menandakan terjadinya proses diferensiasi sel yang ditunjukkan oleh penambahan tinggi tunas okulasi (Tabel 3).

Hasil penelitian menunjukkan pengaruh nyata perlakuan ekstrak bawang merah terhadap okulasi jeruk manis di Distrik Kurulu, Kabupaten Jayawijaya. Hasil penelitian menunjukkan pengaruh nyata oleh perlakuan M2 (konsentrasi $50 \%$ ) dengan nilai rerata 
sebesar 7,72 $\mathrm{cm}$ yang berbeda nyata dengan perlakuan kontrol (M0) (Tabel 3).

Bawang merah diketahui mengandung karbohidrat, protein, lemak, vitamin, dan mineral. Kandungan kimia lain yang terdapat pada bawang merah antara lain adalah minyak atsiri yang salah satunya allin, dan fitohormon berupa auksin (Setiawati, et al. 2008).

Tabel 3. Rerata Tinggi Tunas

\begin{tabular}{ccc}
\multirow{2}{*}{ Perlakuan } & \multicolumn{2}{c}{ Waktu Pengamatan } \\
\cline { 2 - 3 } & $30 \mathrm{HSO}$ & $60 \mathrm{HSO}$ \\
\hline M0 & $5,76 \mathrm{~b}$ & $6,88 \mathrm{c}$ \\
M1 & $7,26 \mathrm{a}$ & $8,45 \mathrm{~b}$ \\
M2 & $7,72 \mathrm{a}$ & $11,06 \mathrm{a}$ \\
M3 & $7,02 \mathrm{a}$ & $9.30 \mathrm{~b}$ \\
\hline BNT & 0,719 & 1,11
\end{tabular}

Keterangan: nilai sekolom yang diikuti dengan huruf yang sama menunjukkan tidak berbeda nyata pada uji BNT 5\%

Hal ini yang menyebabkan ekstrak bawang merah dapat berpotensi untuk merangsang pertumbuhan stek.

Seperti yang juga dikemukakan oleh Abidin (1985) yang mengatakan bahwa hormone auksin mempunyai peranan terhadap pengembangan sel dan pertumbuhan akar. Disini auksin akan merangsang pemanjangan sel yang pada akhirnya akan berakibat pada pemanjangan tunas.

Selain itu, di dalam bawang merah juga terdapat kandungan thiamin (vitamin B1) yang berperan dalam proses perombakan karbohidrat menjadi energi dalam proses metabolisme tanaman, akan tetapi thiamin (vitamin B1) agak sulit diserap oleh tanaman. Senyawa allicin dengan thiamin (vitamin B1) di dalam bawang merah dapat membentuk ikatan kimia yang disebut allithiamin. Adanya senyawa tersebut dapat lebih mudah diserap oleh tubuh tanaman dibandingkan dengan vitamin B1, sehingga senyawa tersebut akan membuat vitamin B1 akan lebih efisien dimanfaatkan oleh tanaman (Wibowo, 1988). Hal ini pada akhirnya berpengaruh pada persentase keberhasilan okulasi hidup.

Hasil penelitian terhadap persentase okulasi hidup menunjukkan pengaruh nyata oleh perlakuan M2 (konsentrasi 50\%) (Tabel 4). Hasil penelitian pengamatan keberhasilan okulasi pada 60 HSO menunjukkan pengaruh yang sangat nyata pada perlakuan M2 (konsentrasi 50\%) dengan rerata sebesar 93,33\% dan tidak berpengaruh nyata terhadap perlakuan M0 (Kontrol/tanpa perlakuan).

Tabel 4. Rerata Persentase Keberhasilan Okulasi Hidup (\%) pada 60 HSO

\begin{tabular}{cc}
\hline Perlakuan & Keberhasilan $(\%)$ \\
\hline M0 & $26,66 \mathrm{c}$ \\
M1 & $53,33 \mathrm{~b}$ \\
M2 & $93,33 \mathrm{a}$ \\
M3 & $80,00 \mathrm{a}$ \\
\hline BNT & 27,45
\end{tabular}

Keterangan : nilai sekolom yang diikuti dengan huruf yang sama menunjukkan tidak berbeda nyata uji BNT $5 \%$

Keberhasilan okulasi tersebut diduga karena bawang merah dapat berfungsi sebagai zat pengatur tumbuh (ZPT) alami yang berfungsi untuk merangsang pertumbuhan dan perkembangan tanaman. Menurut Istyantini (1996), penggunaan zat pengatur tumbuh alami lebih menguntungkan dibandingkan 
dengan zat pengatur tumbuh sintetis, karena bahan zat pengatur tumbuh alami harganya lebih murah dibanding zat pengatur tumbuh sintetis, selain itu juga mudah diperoleh, pelaksanaanya lebih sederhana, dan pengaruhnya tidak jauh berbeda dengan zat pengatur tumbuh sintetis. Salah satu sumber zat pengatur tumbuh alami yang dapat digunakan dalam pembibitan dengan menggunakan stek adalah ekstrak bawang merah. Ekstrak bawang merah mengandung zat pengatur tumbuh yang mempunyai peranan mirip Asam Indol Asetat (IAA). Asam Indol Asetat (IAA) adalah auksin yang paling aktif untuk berbagai tanaman dan berperan penting dalam pemacuan pertumbuhan yang optimal (Husein dan Saraswati, 2010).

Zat senyawa yang terdapat pada bawang merah dapat memberikan kesuburan bagi tanaman sehingga dapat mempercepat tumbuhnya buah dan bunga pada tumbuhan (Setyowati, 2004). Ini sangat baik bagi tanaman karena dapat memicu pertumbuhan akar yang nantinya akan memicu meningkatnya pertumbuhan batang tanaman (Alimudin et al. 2017).

Selain keberadaan auksin dalam ekstrak bawang merah, juga ditemui adanya kandungan Giberalin. Giberelin mempunyai peran dalam mendukung perpanjangan sel, aktifitas kambium dan mendukung pembentukan RNA baru serta sintesis protein. Disamping itu giberelin juga mempunyai pengaruh pada aktifitas kambium, aktifitas sel, dan pertumbuhan. Adapun pengaruh pemberian giberelin terhadap pembelahan sel yaitu terjadi pembelahan sel di daerah meristem batang, tumbuh kambium, dan hilangnya dormansi (Heddy, 1990).

Giberelin (GA3) merupakan ZPT yang mempunyai peranan fisiologis dalam pemanjangan batang (tunas), memperbesar luas daun dari berbagai jenis tanaman, berpengaruh terhadap besar bunga dan buah, proses dormansi dari beberapa biji dan mata tunas dapat dihilangkan dengan pemberian GA3. Rendahnya kandungan giberelin endogen diketahui menyebabkan dormannya mata tunas sehingga pemberian giberelin eksogen dapat membantu mematahkan dormansi mata tunas tersebut (Wattimena, 1988).

Selain itu, laju pertumbuhan tunas juga dipengaruhi oleh beberapa faktor lain sebagaimana keadaan fisiologis tanaman itu sendiri dan keseimbangan hormonal. Semakin tinggi konsentrasi hormon sampai dengan batas tertentu laju pertumbuhan tunas meningkat, tetapi pada konsentrasi yang lebih tinggi laju pertumbuhan tunas semakin melambat (Hatimah, 2000). Hal ini, disebabkan terjadinya ketidakseimbangan hormon, laju pertumbuhan tanaman ditentukan oleh aktivitas kambium yang dipengaruhi oleh keseimbangan hormonal pada tempat penempelan tunas (Trisnawan et al. 2017). Pada dasarnya, tanaman akan menyerap ZPT ketika sel-sel masih aktif membelah dan akan kembali pada laju pertumbuhan yang normal 
ketika hormon yang diberikan sudah diserap oleh tanaman (Anwar dan Iqbal, 2010).

\section{KESIMPULAN DAN SARAN}

\section{Kesimpulan}

Ekstrak bawang merah berpengaruh nyata terhadap keberhasilan okulasi hidup (KOH), saat munculnya tunas, jumlah daun umur 30 HSO dan 60 HSO, tinggi tunas umur 30 HSO dan 60 HSO dengan konsentrasi ekstrak bawang merah terbaik bagi okulasi tanaman jeruk manis (Citrus sp) di Distrik Kurulu, Kabupaten Jayawijaya adalah perlakuan M2 (konsentrasi 50\%).

\section{Saran}

Berdasarkan penelitian yang telah dilakukan, untuk meningkatkan pertumbuhan okulasi tanaman Jeruk Manis (Citrus sp.) perlu penelitian lanjutan terkait pengaruh lama perendaman.

\section{DAFTAR PUSTAKA}

Abidin, 1985. Dasar-Dasar Pengetahuan Tentang Zat Pengatur Tumbuh. Angkasa. Bandung.

Alimudin, Syamsiah M. dan Ramli. 2017. Aplikasi Pemberian Ekstrak Bawang Merah (Allium cepa L.) Terhadap Pertumbuhan Akar Stek Batang Bawah Mawar (Rosa sp.) Varietas Malltic. J. Agroscience. 7(1): 194-202.

Anwar A. H. S. dan A. Iqbal. 2010. Pengaruh Pemberian Ekstrak Buah Apel dan Pupuk NPK Terhadap Pertumbuhan Batang atas Okulasi Durian. J. Pembangunan Pedesaan. 10(1): 7-13.

BPS. 2017. Jayawijaya dalam Angka. Papua.

Halim, 2003. Sekilas Jati. Pusat Penelitian dan Pengembangan Bioteknologi dan Pemuliaan Tanaman Hutan. Yogyakarta.

Hardiyanto, A, Supriyanto, A, Sugiyatno, Setiono \& Mulyanto, H. 2010. Panduan teknis, teknologi produksi benih jeruk bebas penyakit, Pusat Penelitian dan Pengembangan Hortikultura, Badan Penelitian dan Pengembangan Pertanian, Kementerian Pertanian.

Hatimah W. 2000. Pertumbuhan Nuselus Jeruk Kacang (Citrus nobilis L.) pada Beberapa Konsentrasi NAA dan BAP. J. Stigma. VII(1): 9-11.

Heddy, S 1990, Hormon tumbuhan, CV Rajawali Press, Jakarta, hlm. 5-54.

Husein, E., Saraswati, R. 2010, Rhizobakteri pemacu tumbuh tanaman. Pupuk organik dan pupuk hayati, 191209.

Iskandar, 1992. Analisis kandungan Auksin di Dalam Bawang Merah. Balai Penelitian Perkebunan Jember. Jember.

Istyantini, M.T.E. 1996. Pengaruh konsentrasi dan macam zat pengatur tumbuh alami terhadap stek pucuk berbagai varietas krisan (Chrysanthenum sp). Skripsi. Jurusan Agronomi. Fakultas Pertanian. Universitas Jember.

Mangoendidjojo W. 2003. Dasar-dasar Pemuliaan Tanaman. Kanisius. Jakarta.

Moore, T, C.1989. Biochemistry and Physiology of Plants Hormones Second Edition. Springer- Verlag, Inc. New York.

Muswita. 2011. Pengaruh konsentrasi bawang merah (Alium cepa L.) terhadap pertumbuhan setek gaharu (Aquilaria malaccencis OKEN). Jurnal Penelitian Universitas Jambi 5(1): 16 - 22.

Rahayu E. Dan N. Berlian. 1999. Bawang Merah. Penebar Swadaya. Jakarta.

Raven, P. H, R. F. Evert, and S. E. Eichhom. 1986. Biology of Plants Fourth Edition. Worth Publisher, Inc. New York.

Setiawati, W., R. Murtiningsih, N. Gunaeni, dan T. Rubiati. 2008. Tumbuhan Bahan Pestisida Nabati. Balai Penelitian Tanaman Sayur. Bandung. $203 \mathrm{hlm}$.

Setyowati, T. 2004. Pengaruh Ekstrak Bawang Merah (Alium cepa L.) dan Ekstrak Bawang Putih (Alium sativum L.) Terhadap Pertumbuhan Stek Bunga Mawar (Rosa sinensis L). Diakses pada tanggal 06 mei 2019.

Siskawati, E., R. Linda., dan Mukarlina. 2013. Pertumbuhan stek batang jarak 
pagar (Jatropha curcas L.) dengan perendaman larutan bawang merah (Allium cepa L.) dan IBA (Indole Butyric Acid). Jurnal Protobiont 2 (3): $167-170$.

Sudirja, 2010. Bawang Merah. http://www.lablink.or.id./agro/bawangm erah.alternariapartarit.html. Diakses tanggal 12 Agustus 2019.

Trisnawan A. S., Sugiyatno A., Fajriani S. dan Setyobudi L. 2017. Pengaruh Pemberian Zat Pengatur Tumbuh pada Pematahan Dormansi Mata Tunas Tanaman Jeruk (Citrus sp.) Hasil Okulasi.

Wattimena, GA 1988, Zat pengatur tumbuh tanaman, Pusat Antar Universitas dan Lembaga Sumber Daya Informasi IPB, Bogor, hlm145.

Wibowo, S. 1988. Budidaya Bawang: Bawang Putih, bawang Merah, dan Bawang Bombay. Penebar Swadaya. Jakarta. 201 hlm.

Wisudiastuti, 1999. Penganakan Bunga Mawar. Nusa Indah: Yogyakarta

Widyastuti Y. E. 2002. Meningkatkan Produksi Jagung. Penebar Swadaya. Jakarta. 